Homo Oeconomicus 30(4): 101-126 •(2013)

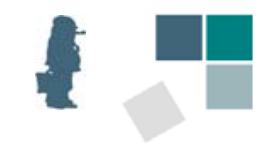

www.acce doverlag.de

\title{
The Political Economy of Human Rights Scandals
}

\author{
Christopher J. Coyne \\ Department of Economics, George Mason University, Virginia, USA \\ (eMail: ccoyne3@gmu.edu) \\ Rachel L. Coyne \\ F.A. Hayek Program for Advanced Study in Philosophy, Politics and Economics at George \\ Mason University, Virginia, USA \\ (eMail: rachel.coyne@rocketmail.com)
}

\begin{abstract}
This paper develops the political economy of human rights scandals involving government agencies. Human rights scandals occur when violations of human rights are made public and cause, or threaten to cause, damage to the reputation of the agencies involved. It is argued that human rights scandals serve as "fire alarms" which alert legislators and the public that existing rules are failing to prevent discretionary human rights abuses by government agents. An analysis of the Abu Ghraib prison scandal is provided to illustrate the economic approach to human rights scandals.
\end{abstract}

Keywords: Abu Ghraib prison, Dehumanization, Human rights, Human rights scandal, rules

JEL Codes: D73, F59, Z18

\section{Introduction}

In 2004, the U.S. Military released the results (the "Taguba report") of an official Army Regulation 15-6 military inquiry into the human rights violations which had occurred over the previous year at Abu Ghraib prison in Iraq. The report revealed the abuse of prisoners being held at Abu Ghraib prison at the hands of U.S. military personnel. These abuses included pouring the chemical liquid from broken lights on prisoners, beating prisoners with a broom handle, sodomizing prisoners, raping a female prisoner, threatening male prisoners with rape, punching and 
kicking prisoners, photographing prisoners naked and in various sexual positions, attaching wires to the limbs and genitals of a prisoner to simulate electrocution, and various psychological tortures including the use of barking dogs and prolonged nudity (Taguba 2004). The Abu Ghraib scandal generated global outrage against those who carried out the violations, as well as the U.S. military and government more broadly. Why do such human rights abuses occur, and do human rights scandals, which are typically seen in a negative light, serve any benefit? This paper answers these questions by developing the political economy of human rights scandals.

Human rights are viewed as universal and applicable to all. As Article 1 of the United Nations Universal Declaration of Human Rights states, "All human beings are born free and equal in dignity and rights. They are endowed with reason and conscience and should act towards one another in a spirit of brotherhood" (United Nations 2012). Similarly, according to Amnesty International (2012), "Human rights are basic rights and freedoms that all people are entitled to regardless of nationality, sex, national or ethnic origin, race, religion, language, or other status.” And while there is not complete consensus regarding what the general category of "human rights" includes-e.g., positive versus negative rights-most would agree that it should include protection against the violence that occurred at Abu Ghraib. When we use the terms "human rights violations" or "human rights abuses," we are referring to these more extreme acts of abuse and torture which would violate almost any notion of human rights.

In the broadest sense, a scandal is a public incident that offends basic moral sensibilities. As such, a scandal leads to the loss of reputation of those accused, or convicted, of the scandalous act. This loss of reputation can be incurred by a specific individual or by an organization. A human rights scandal occurs when violations of rights are made public and cause, or threaten to cause, damage to the reputations of those involved.

In this paper our central focus is on human rights scandals involving government agencies. Establishing constraints on government to prevent the violation of rights is the central issue of constitutional political economy (see Buchanan 1975; Buchanan and Brennan 1985; Weingast 1995; Gordon 2002). As per the well-known "paradox of government," the issue is one of simultaneously empowering government and establishing constraints to avoid abuses of those powers. Well-defined rules will constrain government in abusing its power. However, these constraints are never perfect which can result in "administrative evils" whereby governments use their power for harmful purposes (see Adams 
and Balfour 2004). ${ }^{1}$ We argue that human rights scandals serve the important function of "fire alarms" which reveal the weakness or incompleteness of constraints and provide an opportunity to refine or establish constraints on government agencies to curtail further violations. ${ }^{2}$

Our analysis contributes to three strands of literature, the first of which is the aforementioned literature on constitutional political economy. This literature is focused on the role of rules in constraining government. Our contribution to this literature is to discuss the role of rules in the context of human rights scandals. Second, we contribute to the literature on dehumanization, which is largely based in social psychology. We emphasize the role of rules in preventing dehumanizing acts which are at the foundation of human rights abuses. Finally, we contribute to the research on bureaucracy, and specifically to the literature on the production of rules relating to bureaucratic behavior. This literature explores mechanisms for the optimal control of the discretionary behavior of bureaucrats. We contribute to this strand of research by clarifying the "fire alarm" function that scandals play in illuminating incomplete or absent rules.

We proceed as follows. The next section discusses the role of dehumanization as the foundation of human rights abuses. We review the dehumanization literature in social psychology and reframe it in terms of the rational choice framework with specific emphasis on the role of rules in facilitating or preventing dehumanizing acts associated with human rights violations. Section 3 offers the economic approach to human rights abuses. We consider the benefits and costs of engaging in human rights abuses with specific focus on the role of rules in influencing these benefits and costs. Section 4 discusses human rights scandals as "fire alarms" which serve to reveal gaps in the rules constraining the discretionary behavior of government agents. Section 5 explores the anatomy of the Abu Ghraib prison scandal in light of our theory. Section 6 concludes with the implications of our analysis.

\footnotetext{
${ }^{1}$ Rejali (2007) argues that in the twentieth century, developed democracies-e.g., Britain, France, the U.S. - have exported torture techniques - methods that do not leave marks or scars - that have set the global standard for torture. Parry (2010) argues that torture is a normal part of the coercive state apparatus. Within this context, he argues that Abu Ghraib is the most recent iteration of torture which includes violent repression of certain groups and minorities throughout U.S. history, and other many other instances violence to maintain control and order.

${ }^{2}$ For a discussion of the lack of precision in rules due to vagueness or under specification, see March and Olsen (1985).
} 


\section{Dehumanization: The Foundation of Human Rights Abuses}

An existing literature in psychology explores the role of "dehumanization" in extreme human rights abuses. Dehumanization refers to the cognitive process by which one person views another as less than human. Abusive acts occur when people act on the cognitive process of dehumanization to harm others. Smith makes the distinction and connection between "dehumanization" and "harmful acts" clear when he notes that "...dehumanization is something psychological. It occurs in people's heads. It's an attitude—a way of thinking about people - whereas harming them is a form of behavior, a kind of doing rather than a kind of thinking" (2011: 28, italics original). These acts of abuse and harm, which underpin human rights violations, can take on a variety of forms including extreme physical and mental abuse, torture, rape, and genocide, among other acts.

Literature in cognitive psychology concludes that all people have the natural tendency to dehumanize others to some degree (see Leyens et al., 2000; Leyens et al. 2001; Leyens et al. 2003). Biological explanations for this tendency include a "self-humanization bias," whereby people view themselves as more human than others and treat in-group members as more human than out-group members (see Haslam et al. 2005; Cortes et al. 2005; Zimbardo 2007: 312). Given the universal impulse to dehumanize others, the interesting puzzle is why in some instances, but not in others, the cognitive tendency to dehumanize others is transformed into acts of extreme abuse which impose significant harms on other people.

One potential explanation can be found in a longstanding debate in psychology focused on "dispositional" versus "situational" contexts in explaining how people behave. Situation-based theories explain abusive acts by focusing on how certain circumstances corrupt otherwise good people and cause them to do evil (see Zimbardo 2007). Disposition-based theories, in contrast, emphasize that abusive acts are often carried out by those with certain personality traits which predispose them to engage in evil acts (Donnellan, Fraley, Krueger 2007; Mastroianni 2007). At the core of the disposition-situation debate in psychology is the question of whether personality traits are significant enough to explain differences in behavior across contexts. The issue revolves around the variability of behavior. If a behavior is invariant to the context, then it can be attributed to a specific personality trait. In contrast, if individual behaviors vary across contexts and are highly correlated with the behavior of others in the same context, then the behavior cannot be attributed to individual disposition.

These alternatives represent the two sides of the long-standing disposition-situation debate. On the one side, the "disposition view" holds 
that personality traits are largely invariant across situations, implying that a person's disposition is the main factor driving behaviors. ${ }^{3}$ In contrast, the "situation view" holds that because of the variance in behavior, situational context-i.e., role definition, group dynamics, environment, etc.- drives how people act. ${ }^{4}$ According to the latter view, personality traits are either irrelevant or do not exist at all. ${ }^{5}$

In what follows we provide an explanation for human rights abuses grounded in the economic approach. This approach focuses on the logic of choice grounded in the relative price of different courses of action. The economic approach to human rights violations does not require any special assumptions regarding disposition. Instead, the economic approach focuses on how rules-internal and external-influence the net benefit of engaging in dehumanizing acts. Rules create parameters on both private and public activity to establish and maintain social harmony and peace (Brennan and Buchanan 1985: ix). Rules can be formal-e.g., legislation—or informal—e.g., norms, beliefs—in nature. The economic approach emphasizes that rules serve as prices which influence the net

${ }^{3}$ Early theoretical work by Allport (1937) and empirical work by Eysenck (1944), who developed a two-scale classification for personality, provided the foundation for the disposition view. Subsequent work by Epstein (1979, 1983), Funder and Ozer (1983), Ozer and Benet-Martinez (2006), and Noftle and Robins (2007) provided further support for the disposition view. In addition, research by personality psychologists on the structure of traits both within individuals and across cultures (see Goldberg 1993, Benet and Waller 1995, Clark and Watson 1999, Ashton and Lee 2007) concluded that personality traits are stable within individuals over their lifespan (see Block 1971, Roberts and DelVecchio 2000).

${ }^{4}$ The origins of the situation view are typically linked to Mischel (1968) who argued that personality is variable across time and contexts such that individual personality traits cannot accurately predict behaviors. Further support of the situation view was provided by Ross and Nesbit (1991), among others, who showed how situations affected behavior in a variety of contexts.

${ }^{5}$ It should also be noted that eventually a synthesis of the two views emerged (see Fleeson and Noftle 2008). The seeds of this synthesis had been planted as far back as the 1970s (see Hogan, DeSoto, and Solano 1977), although it did not start to gain widespread attention until the 1990s (see Mischel and Shoda 1995) and 2000s (see Fleeson 2001). Over time this synthesis led to the emergence of a third alternative, termed "interactionism." Interactionism holds that it is the interaction between personality traits and situational contexts that influences behaviors (see Kenrick and Funder 1988). The interactionist view holds that it cannot be assumed that disposition or situations are a better predictor of behavior. This view is supported in a recent meta-analysis of 25,000 social psychology studies by Richard, Bond, and Strokes-Zoota (2003) who find that the magnitude of dispositional effects in existing research are nearly the same as situational effects. 
benefit of engaging in certain behaviors. Changes to rules will change the incentive structure facing individuals, ultimately resulting in changes in outcomes. This logic is at the core of the economic approach to human rights abuses. Both formal and informal rules will influence the net benefit of acting on the cognitive process of dehumanization. Where the rules raise the net cost of abusive acts, people will tend to engage in less of them, all else constant.

Note what this entails for the disposition-situation debate as it relates to human rights violations. The economic approach recognizes that both factors can influence the net costs of engaging in human rights violations. In other words, there is not necessarily a trade-off between disposition and situational contexts where one or the other matters as a monocausal explanation for such violations. Instead, both influence the decision calculus of the individual determining whether or not to engage in human rights abuses. This is important because despite the increased attention paid to the interactionist alternative, Funder (2006: 22) indicates that many psychologists continue to "to treat the relative contributions of person and situation to behavior as a zero-sum game." The economic approach requires no such treatment. In contrast, it allows us to treat different factors as influencing the net benefit of human rights abuses in a variety of ways. In some instances the internal-i.e., dispositional-rules and external-i.e., situational—rules will reinforce one another to raise or lower the net benefit of violating human rights. In other instances the two payoffs associated with each type of rule will move in opposite directions, with the net benefit of human rights abuses being determined by the relative magnitude of the payoff generated by each type of rule.

\section{The Economic Approach to Human Rights Abuses}

Surprisingly, few economists have written on dehumanization and human rights abuses. One exception is Glaeser (2005) who develops the "political economy of hatred." In doing so he offers a model for the interaction of the supply and demand of hate-creating stories. He offers insight into the supply of these stories by politicians and the demand for hate stories by voters. Hate-inducing stories are supplied by politicians to discredit their opponents. These stories are demanded by voters when there is a weak incentive to learn the truth. While Glaeser's model clarifies the role of hatred in political contexts, it does not offer insight into broader instances of human rights violations. Abusive acts can be motivated by hatred, but they need not be, as there are a variety of other potential factors (discussed further below) influencing such behaviors.

In order to develop a basic economic model of human rights abuses, we begin by identifying the main factors contributing to the net benefit of 
engaging in such behaviors. At the core of our model are the interactions between two main categories of players involved in preventing or committing human rights violations. The first category is "authoritygranting individuals," which includes those with the ability to grant subordinates power, including the discretion to engage in abusive acts that violate human rights. Examples may include government leaders, military or militia leaders, and prison wardens, among others. The second category consists of subordinates to the authority-granting individuals who are empowered with the ability to commit human rights violations if they so choose. For example, a prison warden (an authority-granting individual) may grant prison guards (subordinates) the power to control the prison population. The prison guard then has to choose among a variety of behaviors, including torture and abuse, to achieve this end.

Our focus on these two categories of players comes from the classic research by Milgram $(1963,1974)$ who identified the important relationship between authorities and subordinates in harming other people. ${ }^{6}$ We extend this logic to human rights violations. Within our framework, authority-granting individuals provide subordinates with some discretionary power which includes the ability to commit abusive acts if they so choose. The subordinate must then decide whether to commit the abusive acts. An array of informal and formal rules will influence how the subordinate decides to utilize his discretionary power.

These categories of players are context specific, as are the scope and scale of authority. Further, one can envision a set of overlapping relationships whereby the same person simultaneously falls into both categories in different segments of a hierarchy. For example, a warden is an authority-granting individual in the context of the warden-prison guard relationship. However, the warden is a subordinate in the context of the Department of Corrections-warden relationship. The Department of Corrections grants authority to the warden, including the authority to subsequently grant some range of discretionary powers to prison guards. Given these categories of players, the following benefits and costs are relevant to the decision of whether to engage in human rights abuses.

\subsection{Benefits of Human Rights Abuses}

A. Direct Consumption: For sadists, human rights violations are a consumption good. They enjoy inflicting, or observing others inflict, pain on people. Sadists benefit from acts of abuse precisely because these

${ }^{6}$ For a discussion of the controversies surrounding Milgram's research, see Miller (1986). For current perspectives on Milgram's research, see Blass (2000). 
behaviors, in themselves, yield a high payoff. "Open sadists” benefit from the actual act of committing acts of violence against others. The acts of open sadists generate a positive spillover for "repressed sadists" who gain utility by observing acts of violence committed by open sadists. To provide an example of violence as direct consumption, consider a quote from a U.S. soldier recounting the experience in Vietnam, "I enjoyed the shooting and killing. I was literally turned on when I saw a gook get shot” (as quoted in Baker 1986: 66). As another example, consider the actions of the "Kill Team" in Afghanistan which were publicly revealed in March, 2011. According to reports, members of the 3rd Platoon, Bravo Company committed premeditated murder against innocent civilians for sport, videotaping the murder and posing with the mutilated bodies for photographic keepsakes (see Boal 2011). As these examples illustrate, for some individuals the physical act of harming another person yields a positive payoff in itself.

B. Abuse as a Capital Good: Human rights violations may also yield benefits as an input into producing some other final good (e.g., intelligence and security). To illustrate these benefits, consider the following examples. The torture that took place at Abu Ghraib was initially motivated by orders from superiors to pursue harsher interrogation techniques to secure "actionable intelligence" (Karpinski 2005; Post and Panis 2011). The demand for these enhanced interrogation techniques was driven by the perceived benefit of intelligence which would allow the U.S. government to achieve broader goals in the War on Terror. As another example, prisons utilize a variety of dehumanizing techniques-e.g., uniform clothing and schedules, prisoner numbers instead of names, psychological and physical punishment, etc.- to produce the benefit of increased control and order. In each of these cases, abuse is not an end in itself, but instead an input into a broader production process. In general, when human rights violations can serve as a useful input to achieve some broader goal, it raises the benefit of authorizing, and engaging in, such acts.

\subsection{Costs of Human Rights Abuses}

A. Moral Costs: Internal norms are one type of rule which can regulate human rights abuses. ${ }^{7}$ The strength of internal rules is a function of the moral costs associated with committing abusive acts. Research by Meier and Johnson (1977), Tittle (1980), Grasmick and Green (1980),

${ }^{7}$ For a systematic treatment of internal norms see Coleman (1990). 
Paternoster (1989), and Funk (2005) indicates that informal rules and sanctions, such as remorse, are just as important, if not more important, as formal sanctions for deterring criminal behavior. An existing literature in law and economics argues that adherence to formal law is related to social norms (see McAdams 1997; Cooter 1998, 2000). Similar logic can be extended to human rights violations. Internal norms against harming others constrain abusive behavior by imposing a potential moral cost on the potential abuser. This is important because in the absence of weak or imperfect formal rules, informal norms against abuse can constrain harmful actions even where discretionary space for such behaviors exists.

Internal moral rules against human rights violations are evident in the response of revulsion that many people have when they observe instances of extreme abuse committed by others. For those who have internalized a norm against committing abusive acts against other humans, engaging in such behaviors imposes a positive moral cost in terms of guilt and remorse. All else constant, this lowers the net benefit of engaging in human rights abuses. In contrast, those who have failed to internalize norms against human rights violations, or who have been conditioned against following such norms, will not incur the moral cost of engaging in such acts. Taken together, this implies that the total net cost of engaging in human rights abuses will be higher for those who have internalized informal rules against such acts relative to those who have not internalized such rules, all else constant.

The importance and prevalence of internal rules against human rights abuses is evident in instances where effort and resources are invested in reframing the moral costs associated with harming other people. Reframing efforts aim to position some group of people as less than fully human, which lowers the moral cost of committing abuse against them. Consider, for instance, the use of derogatory labeling of a certain group of people to reframe them as being less than human. For example, the Nazis used an array of terms to dehumanize Jews including "parasites," “vermin,” “demons,” “syphilis,” “cancer,” “excrement,” and "plague” which made committing acts of violence against them easier relative to viewing them as fully human (see Waller 2007: 208).

Such efforts to reframe others as less than human are necessary precisely because the internal moral costs of harming other people are typically high, even in extreme circumstances such as war. Levin and Fox (2008: 9) note that in order to be effective in combat, soldiers must “...learn psychologically to separate the allies from the enemy, treating the latter as less than human. As a result, countless normal and healthy individuals who would never dream of killing for fun have slaughtered the enemy in combat. They are not, in their minds, killing human beingsonly 'gooks,' 'krauts,' or 'kikes.'” It is easier to kill a rat or an enemy of 
God as compared to someone of equivalent humanness. Where such reframing efforts are effective, the internal cost—and the net cost, holding all other costs constant - of engaging in abusive acts falls because the person engaged in the act feels less guilt and shame for engaging in such actions.

The logic of moral costs might also provide insight into "whistleblower" behavior. Whistleblowers are individuals who reveal illegal or morally reprehensible misconduct. Some whistleblowers incur a significant internal cost for observing misconduct and, given such feelings of discomfort, take steps to report the behavior either internally-e.g., within an organization-or externally-e.g., to the general public. In many cases whistleblowers face significant costs (see Mesmer-Magnus and Viswesvaran 2005; Sumanth et al. 2011) for reporting misconductdemotion, suspension, harassment, ostracism, loss of job, etc.-indicating that the moral costs of observing the misbehavior must be significantly high in order for whistleblowers to act. $^{8}$

B. Defiance Costs: Defiance costs are the costs imposed on individuals when they refuse to carry out human rights violations. There are two sources of these costs - costs of defying authority and costs of defecting from a group. The classic Milgram Shock Experiment (Milgram 1963, 1974) and Stanford Prison Experiment (Zimbardo 2007) demonstrated the importance of authority and group dynamics for how individuals perceive the costs and benefits of engaging in certain behaviors.

Consider first the cost associated with defying authority. The magnitude of this cost is dependent on the individual's relative position of authority and the scope of one's discretionary decision-making power. Defying authority typically involves costs ranging from sanction, to loss of opportunities for advancement, to loss of a job, to physical punishment.

To illustrate these defiance costs, consider a military commander who orders a private to carry out an abusive act against another person. The costs of defying a direct order in the military are typically high; therefore, the private may very well engage in the abusive act. Kelman and Hamilton (1989: 46) note that extreme acts of harm, such as torture, are often crimes of obedience defined as "an act performed in response to orders from authority that is considered illegal or immoral by the larger community.”

This has important implications for understanding human rights violations because it implies that if defiance costs are sufficiently high, even an otherwise non-aggressive, non-sadist person will be more likely

${ }^{8}$ For a discussion of the incentives and disincentives facing whistleblowers, see Lipman (2012). 
to engage in abusive acts. In such a case, the individual will be rewarded for fulfilling his role and carrying out the act which achieves the goals set by the authority figure. Where the cost of defiance, and benefit of compliance, is high, people will be more likely to engage in human rights abuses, all else constant.

The second source of defiance costs emerges through group dynamics. An existing literature has identified the importance of group norms and behaviors for the way that individual members of the group act (see Funk 2005). For example, Cialdini (1984) emphasizes how people rely on the examples of those around them as a "social proof" of the appropriate behavior. This logic can be extended to human rights violations, where it has been noted that "There seems to be something about the collective-a small band of marauders, an army battalion, a mob, a social or political organization, an office staff, a nation-that often brings out our worst tendencies” (Waller 2007: 33).

If individual group members see other group members engaging in abusive acts, it may lower the cost of the individual participating for two reasons. First, seeing others commit abusive acts may weaken the internal moral cost experienced by the individual. Under this scenario what a person previously saw as "wrong" is now framed as the "right" way to act given the behaviors of peers.

Second, in following the behaviors of others in participating in the abusive act, the individual may receive a benefit by strengthening his position as a contributing member of the group. For example, if all prison guards abuse prisoners, a prison guard who refrains from doing so may incur the cost of being viewed as an outsider to the group. In contrast, if the guard decides to participate in the abusive act, he receives the benefit of belonging to the group. There is evidence that the need for social approval and acceptance, as well as the desire to be viewed as a team player, can cause individuals to suppress their true feelings. Janis (1972) coined the term "groupthink" to account for unwise decisions made by groups of people. One reason for these unwise decisions is that dissent is withheld or suppressed in the interest of group harmony and cohesion. Groupthink is grounded in a “...concurrence-seeking tendency people engage in when they are deeply involved in a cohesive in-group, when the members' strivings for unanimity override their motivations to realistically appraise alternative courses of action. These in-group pressures lead to a deterioration of mental efficiency, reality testing, and normal judgment” (Janis 1972: 8-9). In such instances people are likely to suffer from what Kuran (1995) calls "preference falsification," whereby individuals refrain from revealing their true preferences for fear of negative retaliation. 
The logic of groupthink and preference falsification can be extended to human rights abuses. For example, Post and Panis (2011) analyze how the conditions for groupthink were present at Abu Ghraib prison, contributing to the emergence and escalation of abuse and torture. This included numerous "mind guards" who attempted to stifle dissent in order to maintain cohesiveness around the end goals of obtaining intelligence (Post and Panis 2011: 61). Groupthink is especially likely in cases where there are high exit costs to individual members of the group. Given the high cost of exiting the group, repeated dealings, and the fact that group members are likely to choose harmony over dissension and conflict, individuals will be more likely to participate in or tolerate acts of abuse.

C. Punishment Costs: Punishment refers to the costs imposed on those committing human rights abuses. Examples would include the loss of a title, job-related benefits, or the job itself, as well as imprisonment. As per the standard economics of crime (Becker 1968), all else constant, punishments and the prevalence of human rights violations are inversely related. In many cases the punishments associated with abusive acts are clearly stated in formal laws. However, where punishments or lines of responsibility are unclear, punishment costs may likewise be unclear to those considering engaging in human rights violations. This lack of clarity can be due to the absence of formal laws, the incompleteness of existing formal laws, or a lack of knowledge of existing laws due to acting in a foreign context.

In the context of Abu Ghraib prison, there was a lack of clarity regarding chains of accountability as well as which acts where considered legal and illegal (see Zimbardo 2007: 324-443). Where punishment and responsibility are unclear, the cost of committing abusive acts falls, leading to more of the behavior. This is especially true for those individuals who enjoy abusive acts as a consumption good, as a lack of clear punishment lowers the cost of indulging in a behavior that yields positive utility for the individual.

D. Collateral Damage Costs: Given the benefits associated with human rights violations, authority-granting individuals may demand these behaviors from subordinates. The end goal may be to obtain information, establish control, or develop a reputation of playing "tough" against certain groups, among other ends. However, the demand for abusive acts can also have collateral damage costs to the authority-granting individuals and institutions such as the loss of reputation and goodwill or the end of strategic relationships. These costs can also fall on innocent citizens who are the victims of violent retaliation for abusive acts committed by members of their government against others. In general, where the 
expected collateral damages associated with abusive acts are high, it will reduce the demand for these behaviors, all else constant.

\section{Human Rights Scandals as Fire Alarms}

The economic approach to human rights violations indicates that rules shape the net benefit of engaging in, or refraining from, human rights abuses. Ideally, rules would exist that limit the discretionary capability of government agencies to engage in abusive behaviors. Such rules would raise the cost of abusive acts, reducing or eliminating violations of human rights. This ideal, however, is unlikely to exist in reality. An existing literature on the role of rules in constraining the discretionary activities of government bureaucracies helps to explain why.

Research on "optimal control" explores how legislators can best monitor the discretionary behaviors of the bureaucracies they are charged with overseeing. At first blush, this would appear to be a case of the standard principal-agent problem where the legislature (the principal) needs to determine mechanisms to monitor bureaucrats (the agent). However, as McCubbins, Noll, and Weingast $(1987,1989)$ point out, the realities of the legislator-bureaucracy relationship are often too complex to be captured in the basic principal-agent model. Key factors complicating the issue are the limited effectiveness of ex post sanctions, high monitoring costs, and the costs that legislators must bear to impose sanctions. Moreover, the control of an agency is often not a simple one-toone relationship, meaning that monitoring and control often entails coordinating numerous institutions and layers of principals. ${ }^{9}$ What then is the best way for legislators to control bureaus?

The literature offers two potential solutions (see McCubbins and Schwartz 1984; Weingast 1984; Wangenheim 2011). One option-_"policy patrol"-is for legislators to take a random sample of an agency's behavior and monitor for deviations. This is akin to the method used by a security guard patrolling a neighborhood. A second option-“fire alarms"-is for legislators to wait until there is a strong protest against bureaucratic behavior which is then investigated and dealt with

${ }^{9}$ Note that the existence of multiple layers may reduce the range of discretionary behaviors that any one principal has, but it also makes overall monitoring and enforcement more costly because of the larger number of actors to police. All else constant, these high monitoring costs increase the possibility of abuse of discretionary powers, albeit of a narrower scope, by any of the many principals. 
appropriately. Whistleblowing activity would be an example of this second option of control. The literature points to the second option as being preferred by the U.S. Congress because it reduces direct monitoring costs and instead shifts those costs to others. ${ }^{10}$

Within this context, human rights scandals can be seen as a sort of "fire alarm" which alerts legislators to inappropriate behaviors on the part of government agents. Thus, scandals reveal either inadequate or absent rules or ineffective monitoring and enforcement which results in a failure to constrain the abusive behavior of bureaucrats. The process through which scandals serve as fire alarms can be understood as follows.

Legislators grant certain powers to a bureaucracy, including some range of discretionary power. For some, but not all, bureaucracies this discretion includes the ability to engage in human rights violations. For example, military operations often include the potential for human rights abuses given the need for discretion by the those "on the ground," as well as the high cost of monitoring their activities. In order to limit abuses, procedural rules are established to provide some constraints on how bureaucrats can behave (see Wangenheim 2011: 64-68). However, these rules are far from perfect. There are monitoring costs which can be quite high due to overlapping control, physical distance, reduced flexibility, and significant monetary costs. Further, rules are incomplete because at the time they are determined, all future scenarios cannot be anticipated $e x$ ante. Situations will emerge in the future for which exiting rules either do not apply, or for which the application is unclear. Such instances leave room for discretionary behavior and, hence, the possibility of abusive behaviors.

At any point in time, the rules governing bureaucratic behavior will influence the various benefits and costs of engaging in human rights abuses discussed in the previous section. For example, rules will influence the extent to which subordinates are rewarded or punished for engaging in abusive behavior (e.g., loss of title or status, imprisonment, etc.). Where human rights abuses occur, it is because the rules are such that the benefits to committing such abuses are viewed by the perpetrators as being greater than the associated costs. Given this, ending human rights abuses is ultimately a matter of (1) adequate feedback to alert legislators to inappropriate behaviors and incomplete rules to prevent such behaviors and (2) an incentive to act on that feedback and either change monitoring

10 See also Aberback (1990), Lupia and McCubbins (1994a, 1994b), and Figueiredo et al. (1999) for discussions of dissenting views in the debate about optimal control. 
practices associated with existing rules or to change the existing rules to further raise the cost of engaging in future abuses.

As fire alarms, human rights scandals serve as an important form of feedback to legislators that government agents are engaged in inappropriate behaviors. Either rules have not been specified which prevent certain abuses, or bureaucrats are failing to follow existing rules meant to curb such behaviors. The party who sounds the fire alarm will vary and may include an internal or external whistleblower, as well as watchdog groups such as the media or human rights groups who advertise the inappropriate behavior to the broader public.

The incentive for legislators to act on the information provided by the scandal will be influenced by a variety of factors. Public pressure from voters will be one influencing factor, as will pressure from relevant interest groups who have a stake in the post-scandal outcome. In deciding whether to respond to the feedback, the legislator may also take into account the additional workload associated with the process of changing existing rules or monitoring mechanisms. And, of course, each legislator is limited in what can be done to single-handedly change existing rules. For example, legislators may be pressured by members of the executive branch to maintain the status quo instead of strengthening rules which constrain the discretionary behavior of bureaus. Legislators may also engage in political theater whereby they offer "cheap talk" regarding the need for new and more stringent oversight while, in reality, they do little to actually change the status quo. For example, it may be cheaper for legislators to investigate or punish a scapegoat, relative to the cost of increasing oversight, to signal to the public that something is being done to address wrongdoing.

The broader point is that while human rights scandals can serve as a fire alarm alerting legislators to either the weak enforcement of existing rules, or missing or incomplete rules, the onset of a scandal in no way guarantees that rules will be changed to prevent future abuses. A large public choice literature highlights that the interaction in democratic politics is characterized by rationally ignorant voters, special interest groups, budget-maximizing bureaucrats, and vote-seeking politicians (see Mueller 2003). The result is the very real possibility of government failure and policy outcomes which reflect persistent inefficiencies. This includes failures to effectively address human rights abuses even when scandals reveal the existence of such behaviors.

\section{Abu Ghraib Prison: The Anatomy of a Human Rights Scandal}

Following the 9/11 attacks, a debate began within the Bush administration regarding the use of interrogation techniques associated with the 
transnational War on Terror. The outcome was the well-known "Bybee memos" (also known as the "8/1/02 Interrogation Opinion" or "Torture memos”) drafted by U.S. Deputy Assistant Attorney General John Yoo and signed by U.S. Assistant Attorney General Jay Bybee. The memos, which were written in response to the President's request for clarification on the U.N. Convention Against Torture, provided guidance to President Bush, the Central Intelligence Agency, and the U.S. Department of Defense on the legal use of torture during the War on Terror. The memo discussed both psychological and physical torture and suggested that acts typically considered to be torture-e.g., waterboarding, long-term sleep deprivation, the use of stress positions, etc.-were legally acceptable under the President's authority. It is these memos that provided the legal foundation for the use of "enhanced interrogation techniques" on those captured as part of the War on Terror and held in a variety of prisons, including the one located in the city of Abu Ghraib in Iraq.

Prior to the U.S. invasion of Iraq in 2003, the Abu Ghraib prison had a reputation for extreme abuse of political prisoners by the Hussein regime. Following the fall of the Hussein government, the prison was looted, leaving it barren. The U.S. military renovated the location, transforming it into a U.S. military-controlled prison. A variety of prisoners were housed at Abu Ghraib which was placed under the control of Colonel Janis Karpinski in June, 2003.

A month later, in July, Karpinski was suspended and an investigation was opened into the U.S. Army's operation of the prison system in Iraq. Motivating the investigation was a series of photos depicting prisoner treatment at the Abu Ghraib prison. The pictures were taken by Corporal Charles Graner, who was considered the leader of the prisoner abuse, and given to Sergeant Joe Darby as keepsakes from their tour in Iraq. Darby eventually turned the pictures, which included the infamous prisoner torture photographs, over to the U.S. Army Criminal Investigation Command. The investigation resulted in the "Taguba report" authored by Major general Antonio Taguba (2004). The main finding of the report (2004: 16) was as follows:

...[B]etween October and December 2003, at the Abu Ghraib Confinement Facility (BCCF), numerous incidents of sadistic, blatant, and wanton criminal abuses were inflicted on several detainees. This systemic and illegal abuse of detainees was intentionally perpetrated by several members of the military police guard force (372nd Military Police Company, 320th Military Police Battalion, 800th MP Brigade), in Tier (section) 1-A of the Abu Ghraib Prison (BCCF). The allegations of abuse were substantiated by detailed witness statements (ANNEX 26) and the discovery of 
extremely graphic photographic evidence...In addition to the aforementioned crimes, there were also abuses committed by members of the 325th MI Battalion, 205th MI Brigade, and Joint Interrogation and Debriefing Center (JIDC).

The various categories of benefits and costs discussed in Section 3 provide insight into the logic underpinning the abuse at Abu Ghraib. Consider first the benefit side, specifically the notion that abuse can be a direct consumption good for some people. In recalling a conversation with Graner regarding the photos of abuse, Darby indicated that Graner said, "The Christian in me knows this is wrong, but the corrections officer in me can't help but love to make a grown man piss himself" (quotes in Sharrok 2008). As this quote indicates, Graner viewed abuse as a consumption good yielding direct utility. More generally, an analysis of the scandal concluded that "the military police at Abu Ghraib treated their charges as if they were sub-human, evincing no empathy for them; they were actually entertained by the prisoners' shame and humiliation" (Post and Panis 2011: 64).

Prisoner abuse was also viewed as an input into the broader process of winning the War on Terror. As illustrated by the very existence of the Bybee memos, in the wake of the 9/11 attacks, the Bush administration placed a premium on winning the "war" even if it meant committing acts that would traditionally be considered human rights abuses. This culture of winning at all and any costs was clearly at play at Abu Ghraib. Under pressure from the Bush administration to demonstrate progress in the fight against terrorism, the Central Intelligence Agency (CIA), in turn, put pressure on the military to secure "actionable intelligence" from prisoners held at Abu Ghraib and elsewhere. Indeed, during their trials for prisoner abuse, several soldiers who were stationed at Abu Ghraib claimed that they were simply "following orders" and used this as the centerpiece of their defense (see Post and Panis 2011).

For example, Private Ivan L. Frederick, who was stationed at Abu Ghraib, testified that he was ordered by a CIA agent to "soften them [the detainees] up" and that "he [the CIA agent] did not care what the soldiers did, ‘just don't kill him”” (Reid 2005). Private Lynndie England indicated that the CIA was aware of what the guards at Abu Ghraib were doing to detainees and rewarded the behavior. In one interview she stated that “They'd come back and they'd look at the pictures, and they'd state, 'Oh, that's a good tactic, keep it up. That's working. This is working. Keep doing it. It's getting what we need'” (quoted in CBS News 2009).

Of course one might argue that these claims are self-serving on the part of those involved in the scandal. By placing blame on the "higher ups," those involved are able to justify their actions on the grounds of following 
orders. However, there is reason to believe, independent from the quotes of those accused of abuse, that guards were ordered to engage in questionable behaviors toward detainees. For example, in its review of the foundation of interrogation operations in Abu Ghraib, the Tugaba report (2004: 8) notes that interrogators made clear that "it is essential that the guard force be actively engaged in setting the conditions for successful exploitation of the internees.” This implies that even if those involved in the scandal are exaggerating the extent of the direct orders they received, the overarching culture was one that left room for, if not explicitly encouraged, the mistreatment of detainees for "successful exploitation."

Now consider the cost side of human rights abuses in the context of Abu Ghraib prison. The absence of clear rules and punishments associated with prisoner abuse lowered the cost of prison guards committing human rights violations. For one, the aforementioned Bybee memos defined what constituted torture so narrowly that many of the acts committed at Abu Ghraib fell outside that definition, making them legally acceptable. Further, to the extent that prison guards were ordered, and rewarded, for engaging in such behaviors, it lowered the cost of engaging in abusive behaviors and raised the cost of defying orders. The Taguba report (2004: 18 ) indicates that "Military Intelligence (MI) interrogators and Other US Government Agency's (OGA) interrogators actively requested that MP guards set physical and mental conditions for favorable interrogation of witnesses." Granted, the report does not indicate what exactly these "conditions" were supposed to entail, but it is precisely the lack of boundaries and clear punishments for rule violations that left discretionary space for abusive behaviors. Adams, Balfour and Reed (2006: 687) highlight this ambiguity in rules and procedures at Abu Ghraib when they write, "The line between the permissible and the prohibited was blurred by varying legal opinions, a lack of clearly established written procedures, and a perceived need to adapt to a new paradigm of warfare in which the enemy did not adhere to the established rules of land warfare."11

Further contributing to the costs of defiance was the prevalence of "groupthink" at multiple levels. The Bush administration's emphasis on winning the war on terror at all costs led to an "us" [the U.S.] versus "them" [all real and potential terrorists] mentality whereby the out-group ("them") were viewed as a direct threat to the safety and well-being of the in-group ("us”). This mentality, along with the broader lack of clear rules

${ }^{11}$ See also James (2008). He attributes the Abu Ghraib scandal to a perfect storm of young and inexperienced soldiers, lack of control among noncommissioned officers, lack of clarity regarding mission and interrogation procedures, and lack of command and leadership. 
and punishments provided a justification for extreme actions, including human rights abuses. Further, members of the in-group who questioned the techniques employed were threatened with direct (e.g., demotion, suspension) or indirect (e.g., social ostracism) penalties. The result was that "Anyone knowledgeable about the practices being endorsed [at Abu Ghraib] who questioned the propriety of their use and whether the U.S. should be involved in torture was treated with contempt, as someone who didn't understand the danger which justified violating any norm” (Post and Panis 2011: 61). This mentality contributed to an unquestioning attitude toward abuse which became routinized in the operations of Abu Ghraib.

Finally, consider how the Abu Ghraib prison scandal illustrates the role of scandals as "fire alarms." Recall that there are two ways for legislators to monitor agencies. One is some form of policing or direct monitoring of behavior or a sample of behavior. The other entails legislators waiting for the revelation of inappropriate behaviors which are then addressed. A key factor in determining the preferred form of control is monitoring costs. And in the case of Abu Ghraib, those costs were quite high.

There were numerous government agencies involved in the prison's operation, and these agencies were responsive to numerous influences, including the executive branch. These numerous layers of bureaucracy, combined with the crisis mentality surrounding the War on Terror, led to a lack of clear accountability, responsibility, communication, and visibility, all of which contributed to high monitoring costs. The Taguba report (2004: 30) captured this succinctly when it noted that "Contributing factors [to the Abu Ghraib prison scandal] were inexperienced guards, lapses in accountability, complacency, lack of leadership presence, poor visibility, and lack of clear and concise communication between the guards and the leadership." Given such high monitoring costs, it is not surprising that it took a fire alarm to alert legislators, and the general public, to the lack of rules preventing abusive behaviors by members of the military.

The revelation of the scandal was driven by a whistleblower, Joe Darby, whose actions illustrate the role of moral costs discussed in the previous section. After Graner showed Darby the photos of abuse, Darby waited three weeks to report the abuse to the Army investigation office. During this period Darby was engaged in an internal conflict of whether he should report the abusive behaviors of his colleagues and, in some cases, friends (Sharrock 2008). Further, after reporting the photos, Darby incurred significant costs including death threats and the public revelation of his name (a supposed "accident”), by then Secretary of Defense Donald Rumsfeld during his Congressional testimony. Rumsfeld "slipped” and 
revealed Darby's name despite promises of anonymity made by military investigators.

The scandal resulted in a public debate about the role of torture in the War on Terror and the limits of government authority and power in this regard. The Bybee memos had already been under review prior to the breaking of the Abu Ghraib scandal. Bybee resigned his position in the Department of Justice in 2003 and was replaced by Jack Goldsmith. Goldsmith had reviewed the Bybee memos months before the scandal broke and had come to the conclusion that they should be withdrawn. However, the breaking of the Abu Ghraib scandal accelerated this process. Writing about the role of the scandal, Goldsmith (2007: 159) notes that, "Obviously the public release of the opinions and the resulting outcry [from the Abu Ghraib scandal] precipitated my decision [to withdraw the memos]." The Office of the Legal Council issued new guidelines in 2004 regarding the treatment of detainees. Within two days of taking office in 2009, President Obama attempted to make a clean break from the Bybee memos and the Abu Ghraib scandal. An Executive Order signed on January 22, rescinded all previous Office of the Legal Council guidelines issued between 2001 and 2009 dealing with the detention and interrogation of detained individuals.

This outcome illustrates that in addition to drawing attention to gaps in existing rules, human rights scandals also provide an opportunity for making changes to the rules. Of course an opportunity for a change in the rules is not the same as an actual change. Whether the opportunity is acted upon is a function of the incentives facing legislators. To date, it is unclear that the situation in the U.S. has changed dramatically since the Abu Ghraib scandal broke. For example, there are still reports of human rights abuses by the U.S. government despite the Abu Ghraib scandal (see, for example, Amnesty International 2011, Human Rights Watch 2013). Further, the Obama administration has taken an extremely strong stance against whistleblowers and leaks on issues related to national security broadly understood. As one report notes, "When President Barack Obama took office, in 2009, he championed the cause of government transparency, and spoke admiringly of whistle-blowers, whom he described as 'often the best source of information about waste, fraud, and abuse in government.' But the Obama Administration has pursued leak prosecutions with a surprising relentlessness" (Mayer 2011). This reality illustrates the point that it is ultimately the incentives that legislators face that will influence how they respond to abuse scandals. Where there is weak pressure from the public to change, the status quo will persist.

\section{Concluding Remarks}


Our analysis has several implications. First, human rights violations are fundamentally a function of rules. Rules - informal and formal-influence the net benefit of engaging in human rights abuses. Where human rights abuses occur, it is evidence of incomplete, or altogether absent, rules which adequately raise the cost of such behaviors. Focusing on the role of rules in human rights abuses avoids having to make judgments about the disposition of individuals and, instead, focuses on the relative costs facing individuals in different rule contexts. In the context of human rights violations, the recognition of the role of rules is especially important in times of crisis, such as the War on Terror. It is in these situations, where the pull to "do something" is strongest, that we are most likely to see significant room for discretion with relatively few constraints on behaviors, where human rights abuses are most likely to occur.

Second, human rights scandals serve as "fire alarms" which reveal the absence of appropriate rules to discourage such behaviors. Rules are intended to constrain government behaviors, including the abuse of power by harming people. In this regard rules are often effective in preventing human rights abuses from occurring in the first place. Rules, however, are often underspecified or imperfectly enforced due to positive monitoring costs. Given these realities, scandals serve to alert legislators and the public that rules constraining inappropriate behaviors are lacking or unenforced.

Finally, while human rights scandals can serve as a feedback mechanism alerting us to ineffective rules, the onset of a scandal is no guarantee that rules will be changed to prevent future abuses. Ultimately, rule changes require that the appropriate legislators have an incentive to proactively change and enforce rules to end abusive behaviors. Given the existing political structure, the pressure for change would need to come from voters or political donors. For a variety of public choice issues, this pressure can be weak or nonexistent. More broadly, the implication is that when thinking about preventing human rights abuses, it is important to ensure, or at least consider, the incentives that are in place for rule makers to act on the feedback provided by scandals. Absent the incentive to change rules accordingly, scandals will be ineffective in engendering broader rule modifications necessary to prevent future human rights violations.

\section{References}

Aberbach, J. (1990), Keeping a Watchful Eye, Washington, D.C.: Brookings Institute.

Adams, G.B., Balfour, D.L. (2004), Unmasking Administrative Evil, Armonk, NY: M.E. Sharpe. 
Adams, G.B., Balfour, D.L., Reed G.E. (2006), “Abu Ghraib, Administrative Evil, and Moral Inversion: The Value of 'Putting Cruelty First'," Public Administration Review 66: 680-693.

Allport, G. W. (1937), Personality: A Psychological Interpretation, New York, NY: Henry Holt.

Amnesty International (2011), USA See No Evil: Government Turns the Other Way as Judges Make Findings About Torture and Other Abuses, London, UK: Amnesty International Publications.

Amnesty International (2012), Basic Human Rights, Available online: http://www.amnestyusa.org/research/human-rights-basics. Accessed 8/1/12.

Ashton, M. C., and Lee, K. (2007), "Empirical, theoretical, and practical advantages of the HEXACO model of personality structure," Personality and Social Psychology Review 11: 150- 166.

Baker, M. (1986), Nam: Vietnam War in the Words of the Men and Women Who Fought There, New York, NY: Quill.

Becker, G. (1968), "Crime and Punishment: An Economic Approach," Journal of Political Economy 76: 169-217.

Benet, V., and Waller, N.G. (1995), "The 'Big Seven' model of personality description: evidence for its cross-cultural generality in a Spanish sample,” Journal of Personality \& Social Psychology 69: 701718.

Blass, T. (2000), Obedience to Authority: Current Perspectives on the Milgram Paradigm, Mahwey, NJ: Lawrence Erlbaum Associates.

Block, J. (1971), Lives Through Time, Berkeley, CA: Bancroft.

Boal, M. (2011), “The Kill Team,” Rolling Stone, March 27.

Brennan, G. and Buchanan, J.M. (1985), The Reason of Rules: Constitutional Political Economy, Cambridge, MA: Cambridge University Press.

Buchanan, J. M. (1975), The Limits of Liberty: Between Anarchy and Leviathan, Chicago, IL: Chicago University Press.

CBS News, (2009), Female GI in Abuse Photos Talks, February 11. Available online:http://www.cbsnews.com/2100-500257_162616921.html

Clark, L. A., and Watson, D. (1999), “Temperament: A new paradigm for trait psychology,” in: L.A. Pervin \& O. P. John (eds.), Handbook of Personality, New York, NY: Guilford Press.

Coleman, J.S. (1990), Foundations of Social Theory, Cambridge, MA: Harvard University Press.

Cooter, R. (1998), “Expressive Law and Economics,” Journal of Legal Studies 27: 585-608.

Cooter, R.. (2000), "Do good laws make good citizens? An economic analysis of internalized Norms,” Virginia Law Review 86: 1577-1601. 
Cortes, B. P., Demoulin, S., Rodriguez, R.T., Rodriguez, A.P. and Leyens, J. Ph. (2005), "Infra humanization or familiarity? Attribution of uniquely human emotions to the self, the ingroup, and the outgroup," Personality and Social Psychology Bulletin 31: 243-253.

Epstein, S. (1979), "The stability of behavior: I. On predicting most of the people much of the Time," Journal of Personality and Social Psychology 37: 1097-1126.

Epstein, S. (1983), Aggregation and beyond: Some basic issues on the prediction of behavior, Journal of Personality 51: 360-392.

Eysenck, H. (1944), "Types of personality: a factorial study of 700 neurotics,” Journal of Mental Science 90: 851-861.

Figueiredo, R.J.P., Spiller, P.T., Urbiztondo, S. (1999), “An Informational Perspective on Administrative Procedures," Journal of Law, Economics, and Organization 15: 283-305.

Fleeson, W. (2001), "Towards a structure- and process-integrated view of personality: Traits as density distributions of states," Journal of Personality and Social Psychology 80: 1011- 1027.

Fleeson, W. and Noftle, E. (2008), "The End of the Person-Situation Debate: An Emerging Synthesis in the Answer to the Consistency Question," Social and Personality Psychology Compass 2/4: 16671684.

Funder, D.C. (2006), "Towards a resolution of the personality triad: Persons, situations, and behaviors," Journal of Research in Personality 40: 21-34.

Funder, D. C., and Ozer, D.J. (1983), "Behavior as a function of the situation,” Journal of Personality and Social Psychology 44: 107-112.

Funk, P. (2005), "Government action, social norms, and criminal behavior," Journal of Institutional and Theoretical Economics 161: 522-35.

Glaeser, E. (2005), “The Political Economy of Hatred,” Quarterly Journal of Economics 120: 45-86.

Goldberg, L. R. (1993), "The structure of phenotypic personality traits," American Psychologist48: 26-34.

Goldsmith, J. (2007), The Terror Presidency, New York, NY: W.W. Norton and Co.

Gordon, S. (2002), Controlling the State: Constitutionalism from Ancient Athens to Today, Cambridge, MA: Harvard University Press.

Grasmick, H. G. and Green, D.E. (1980), "Legal Punishment, Social Disapproval and Internalization as Inhibitors of Illegal Behavior,” Journal of Criminal Law and Criminology 71: 325-335.

Haslam, N., Bain, P., Douge, L., Lee, M., Bastian, B. (2005), "More human than you: Attributing humanness to self and others," Journal of Personality and Social Psychology 89: 937-950. 
Hogan, R., DeSoto, C.B., and Solano, C. (1977), "Traits, tests, and personality research,” American Psychologist 32: 255-264.

Human Rights Watch (2013), "Iraq 10 Years Later, Creeping Authoritarianism,” March 19, Available online: http://www.hrw.org/news/2013/03/19/iraq-10-years-later-creepingauthoritarianism

James, L.C. (2008), Fixing Hell: An Army Psychologist Confronts Abu Ghraib, New York, NY: Grand Central Publishing.

Karpinski, J. (2005), One Woman's Army: The Commanding General of Abu Ghraib Tells HerStory, New York, NY: Random House.

Kelman, H.C. and Hamilton, V. (1989), Crimes of Obedience: Toward a Social Psychology of Authority and Responsibility, New Haven, CT: Yale University Press.

Kenrick, D. T., and Funder, D.C. (1988), "Profiting from controversy: Lessons from the person situation debate," American Psychologist 43: 23-34.

Kuran, T. (1995), Private Truths, Public Lies: The Social Consequences of Preference Falsification, Cambridge, MA: Harvard University Press.

Levin, J. and Fox, J.A. (2008), "Normalcy in Behavioral Characteristics of the Sadistic Serial Killer,” in: R.N. Kocsis (ed.), Serial Murder and the Psychology of Violent Crimes, New Jersey: Humana Press.

Leyens, J. P., Paladino, P.M., Rodriguez, R.T., Vaes, J., Demoulin, S., Rodriguez, A.P., Gaunt, R. (2000), "The emotional side of prejudice: The role of secondary emotions," Personality and Social Psychology Review 4: 186-197.

Leyens, J. P., Rodriguez, A.P., Rodriguez, R.T., Gaunt, R., Paladino, P.M., Vaes, J., Demoulin, S. (2001), "Psychological essentialism and the attribution of uniquely human emotions to ingroups and outgroups,” European Journal of Social Psychology 31: 395-411.

Leyens, J. P., Cortes, B.P., Demoulin, S., Dovidio, J.F., Fiske, S.T., Gaunt, R., Paladino, M-P, Rodriguez-Perez, A., Rodriguez-Torres, R., and Vaes, J. (2003), "Emotional prejudice, essentialism, and nationalism,” European Journal of Social Psychology 33: 704-717.

Lipman, F.D. (2012), Whistleblowers: Incentives, Disincentives, and Protection Strategies, New York, NY: John Wiley \& Sons.

Lupia, A. and McCubbins, M.D. (1994a), "Learning from Oversight: Fire Alarms and Police Patrols Reconsidered,” Journal of Law, Economics, and Organization 10: 96-125.

Lupia, A. and McCubbins, M.D. (1994b), "Designing Bureaucratic Accountability,” Law and Contemporary Problems 57: 91-126.

March, J.G. and Olsen, J.P. (1985), Ambiguity and Choice in Organizations, New York, NY: Oxford University Press. 
Mastroianni, G.R. (2007), “Zimbardo’s Apple,” Analyses of Social Issues and Public Policy 7: 251-254.

Mayer, J. (2011), “The Secret Sharer,” The New Yorker, available online: http://www.newyorker.com/reporting/2011/05/23/110523fa_fact_maye r?currentPage=all

McAdams, R. H. (1997), "The origin, development and regulation of norms,” Michigan Law Review 96: 338-433.

McCubbins, M.D., Noll, R.G., and Weingast, B.R.(1987), “Administrative Procedures as Instruments of Political Control,” Journal of Law, Economics, and Organization 3: 243-277.

McCubbins, M.D., Noll, R.G., and Weingast, B.R. (1989), "Structure and Process, Politics and Policy: Administrative Arrangements and the Political Control of Agencies,” Virginia Law Review 75: 431-482.

McCubbins, M.D. and Schwartz, T. (1984), "Congressional Oversight Overlooked: Policy Patrols vs. Fire Alarms," American Journal of Political Science 28: 165-179.

Meier, R. F. and Johnson, W. (1977), Deterrence as Social Control: The Legal and Extralegal Production of Conformity, American Sociological Review 42: 292-304.

Mesmer-Magnus, J. R., and Viswesvaran, C. (2005), "Whistleblowing in organizations: An examination of correlates of whistleblowing intentions, actions, and retaliation," Journal of Business Ethics 62: 277-297.

Milgram, S. (1963), "Behavioral Study of Obedience," Journal of Abnormal and SocialPsychology 67: 371-378.

Milgram, S. (1974 [2009]), Obedience to Authority: An Experimental View, New York, NY: Harper Collins.

Miller, A.G. (1986), The Obedience Experiments: A Case Study of a Controversy in SocialScience, Westport, CT: Praeger.

Mischel, W. (1968), Personality and Assessment, New York, NY: John Wiley.

Mischel, W., and Shoda, Y. (1995), “A cognitive-affective system theory of personality: Reconceptualizing situations, dispositions, dynamics, and invariance in personality structure," Psychological Review 102: 246-268.

Mueller, D.C. (2003), Public Choice III, New York, NY: Cambridge University Press.

Noftle, E. E., and Robins, R.W. (2007), "Personality predictors of academic outcomes: Big Five correlates of GPA and SAT scores," Journal of Personality and Social Psychology 93: 116-130.

Ozer, D. J., and Benet-Martínez, V. (2006), "Personality and the prediction of consequential outcomes," Annual Review of Psychology 57: 401-421. 
Parry, J.T. (2010), Understanding Torture: Law, Violence, and Political Identity, Ann Arbor, MI: University of Michigan Press.

Paternoster, R. (1989), "Decisions to Participate in and Desist from Four Types of Common Delinquency: Deterrence and the Rational Choice Perspective," Law \& Society Review 23: 7-40.

Post, J.M. and Panis, L.K. (2011), "Crimes of Obedience: 'Groupthink' at Abu Ghraib,” International Journal of Group Psychotherapy 61: 4966.

Reid, T.R. (2005), “Military Court Hears Abu Ghraib Testimony,” The Washington Post, January 11: A03.

Rejali, D. (2007), Torture and Democracy, Princeton, NJ: Princeton University Press.

Richard, F.D., Bond, C.F., and Strokes-Zoota, J.J. (2003), “One Hundred Years of Social

Psychology Quantitatively Described,” Review of General Psychology 7: 331-363.

Roberts, B. W. and DelVecchio, W.F. (2000), "The rank-order consistency of personality traits from childhood to old age: A quantitative review of longitudinal studies," Psychological Bulletin 126: $3-25$.

Sharrock, J. (2008), Am I a Torturer? Mother Jones, March/April, Available online: http://www.motherjones.com/politics/2008/03/am-itorturer

Smith, D.L. (2011), Less Than Human: Why we Demean, Enslave and Exterminate Others, New York, NY: St. Martin's Press.

Sumanth, J.J., Mayer, D.M., and Kay, V.S. (2011), "Why Good Guys Finish Last: The Role of Justification Motives, Cognition, and Emotion in Predicting Retaliation against Whistleblowers," Organizational Psychology Review 1: 165-184.

Taguba, A. (2004), "Article 15-6 Investigation of the 800th Military Police Brigade," Available online: http://www.npr.org/iraq/2004/prison_abuse_report.pdf

United Nations (2012), "United Nations Universal Declaration of Human Rights,” Available online: http://www.un.org/en/documents/udhr/. Accessed 8/1/12.

Waller, J. (2007), Becoming Evil: How Ordinary People Commit Genocide and Mass Killing, New York, NY: Oxford University Press.

Wangenheim, G. von (2011), "Production of legal rules by agencies and bureaucracies," in: F. Paris (ed.), Production of Legal Rules, Volume 7: Encyclopedia of Law and Economics, Massachusetts: Edward Elgar Publishing, Inc.

Weingast, B. (1984), "The Congressional-Bureaucratic System: A Principal Agent Perspective (with Applications to the SEC)," Public 
Choice 44: 147-191.

Weingast, B. (1995), "The Economic Role of Political Institutions: Market-Preserving Federalism and Economic Development," Journal of Law, Economics, and Organization 11: 1-31.

Zimbardo, P. (2007), The Lucifer Effect: Understanding How Good People Turn Evil, New York, NY: Random House. 